
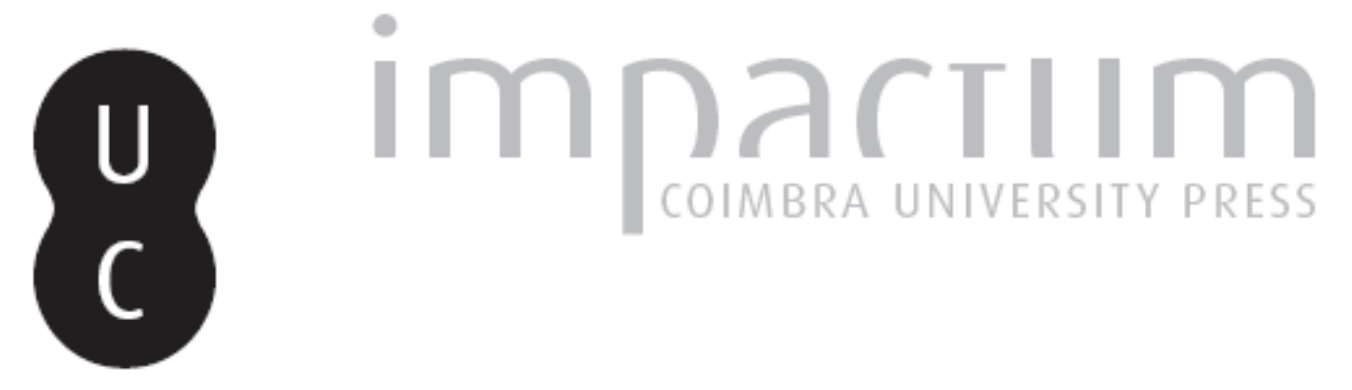

\title{
Regarding rules: from Rimini to Rio
}

\author{
Autor(es): Knight, Terry
}

Publicado por: Editorial do Departamento de Arquitetura

URL persistente:

URI:http://hdl.handle.net/10316.2/37229

DOI:

DOI:http://dx.doi.org/10.14195/1647-8681_5_1

Accessed : $\quad$ 26-Apr-2023 14:18:31

A navegação consulta e descarregamento dos títulos inseridos nas Bibliotecas Digitais UC Digitalis, UC Pombalina e UC Impactum, pressupõem a aceitação plena e sem reservas dos Termos e Condições de Uso destas Bibliotecas Digitais, disponíveis em https://digitalis.uc.pt/pt-pt/termos.

Conforme exposto nos referidos Termos e Condições de Uso, o descarregamento de títulos de acesso restrito requer uma licença válida de autorização devendo o utilizador aceder ao(s) documento(s) a partir de um endereço de IP da instituição detentora da supramencionada licença.

Ao utilizador é apenas permitido o descarregamento para uso pessoal, pelo que o emprego do(s) título(s) descarregado(s) para outro fim, designadamente comercial, carece de autorização do respetivo autor ou editor da obra.

Na medida em que todas as obras da UC Digitalis se encontram protegidas pelo Código do Direito de Autor e Direitos Conexos e demais legislação aplicável, toda a cópia, parcial ou total, deste documento, nos casos em que é legalmente admitida, deverá conter ou fazer-se acompanhar por este aviso.

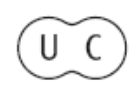




\section{Terry Knight \\ Regarding Rules: \\ From Rimini to Rio}

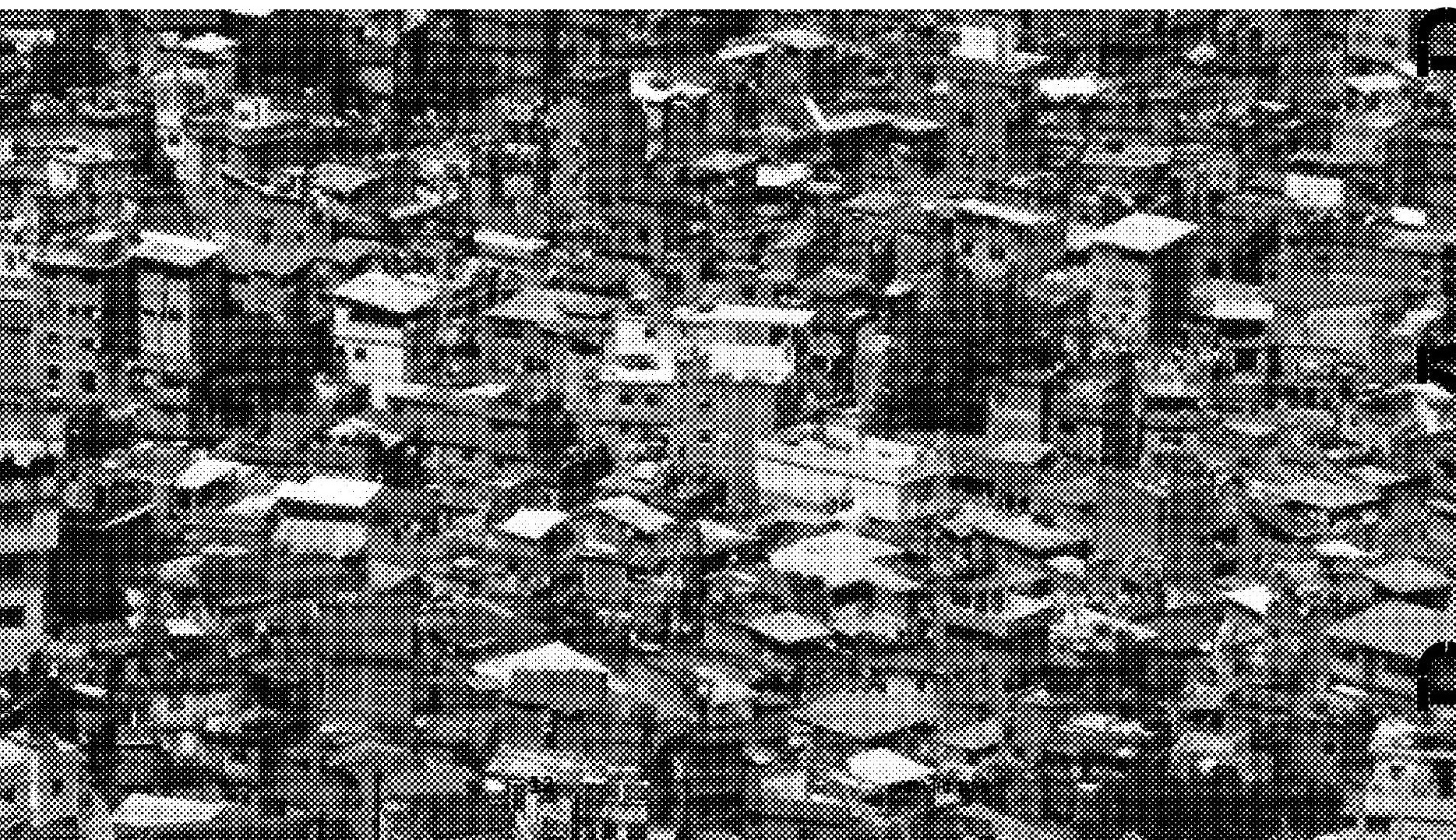




\section{Introduction}

The legacy of Alberti's 15th century treatise, De re aedificatoria (Alberti, 1988), on architectural theory and practice up to the present day is profound and wide-ranging. Indeed, the story of building over the last five and a half centuries is, in part, the story of the diverse interpretations, adaptations, and transformations of the rules of building that Alberti derived from classical architecture and laid down in his treatise. Interestingly, this story of transformations begins with Alberti himself - with his own adaptations and departures from classical rules within his own design practice and for his own time. In so doing, Alberti set the stage for others to transform rules, precedents, and traditions in innovative and context-specific ways.

In this paper, design rules and transformations are introduced through the ideas and work of Alberti, and then expanded through a computational lens, specifically, through the lens of shape grammars. Four computational strategies for transforming designs to produce new ones are outlined and illustrated through prior shape grammar studies. In each strategy, the analysis of precedents is the impetus for design, and rules are the basis for practice. Though the computational format of shape grammars rules is unique and contemporary, the goals and potentials of shape grammars are very much in the spirit of Alberti.

\section{Alberti: from analysis to design, from rules to practice}

Alberti documented his theory and principles for architectural design in his 1452 book De re aedificatoria. His theory derived from an extensive analysis of the architecture of antiquity, based on a first-hand examination of Roman ruins and readings of classical texts including Vitruvius's De architectura. Alberti's rules were many and included ones like these for adding porticoes to a rectangular temple plan:

With a quadrangular temple, the portico may be attached either to the front or to both front and back, or it may be wrapped around the whole cella. Wherever a tribunal projects, there should be no portico. Porticoes on the front of quadrangular temples must never be shorter than the whole width of the temple, and never wider than a third of the length [of the temple]. Porticoes along the sides should have columns the same distance apart as they are from the wall of the interior. Those to the rear may take either form, according to preference.

(Alberti, 1988, pp.197-198).

Alberti's rules were analytic and descriptive, as they were founded on historic architecture. But they were meant to be much more. They were meant to be prescriptive - they were rules for design, rules for designing in Alberti's own time. Given this ambition, one may wonder how Alberti used his own rules in his own design work. How did he proceed from analysis to design, or from rules to practice? Two examples from Alberti's work suggest answers to these questions.

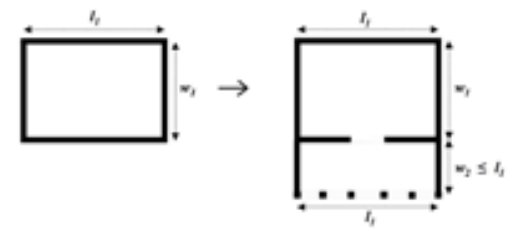

1. A shape rule for adding a portico to a temple front. 
Alberti's first design project was a commission to transform the late Gothic church of San Francesco in Rimini, Italy into a contemporary version of a classical temple, renamed the Tiempo Malastestiano. Construction on the church was never completed but extant models show Alberti's probable design intentions. Alberti approached his design task by adapting his rules in creative ways, essentially by selecting and combining different classical rules for different building types. For example, on the façade he embedded a triple arch in the manner of a Roman triumphal arch, along the sides he introduced an arcaded gallery, and in the back he placed a domed rotunda in the style of the Roman Pantheon. The design is a collage of classical rules adapted for a new context.

A subsequent commission for the redesign of the façade of a Florentine palace, the Palazzo Rucellai, is also telling. The problem here for Alberti was again the problem of adapting classical rules to a contemporary context, specifically, a house on an urban street. The historian Ernst Gombrich describes Alberti's problem and solution thus:

... how was this new [classical] programme to be applied to an ordinary dwelling house in a city street?.... When he [Alberti] built a palace for the rich Florentine merchant family Rucellai, he designed an ordinary three-storeyed building. There is little similarity between this façade and a classical ruin. ... Instead of building columns or half-columns, he covered the house with a network of flat pilasters and entablatures which suggested a classical order without changing the structure of the building. ... Alberti ... merely 'translated' a Gothic design into classical forms by smoothing out the 'barbaric' pointed arch and using the elements of the classical order in a traditional context.

(Gombrich, 1995, pp.179-180).

The Alberti scholar Robert Tavernor further notes that the column proportions and ornamentation of a palace portico according to Alberti's rules are different from the proportions and ornaments Alberti actually used for the Rucellai palace. They are shorter and squatter (Tavernor, 1998, pp.85-89). Alberti adapted his rules to fit the particular street context of the palace. In sum, Alberti's approach to design practice was based on the adaptation and transformation of rules. Tavernor summarizes his approach thus:

In practice, the ideals that frame his [Alberti's] text were tempered by the unique combination of circumstances with which his various patrons presented him, including the intended purpose of the buildings' cultural and physical surroundings. ... It can be concluded, therefore, that however revered the ancient building types, their example is only ever a starting-point for a design...

(Tavernor, 1998, p.201) 
How does Alberti and his approach to analysis and design, and to rules and practice, relate to the work of the shape grammarian?

\section{Shape grammars}

Shape grammars are generative, rule-based design systems.

Unlike Alberti's verbal rules, the rules of a shape grammar are visual or pictorial. Each shape rule is an "if-then" conditional or instruction of the form $A \rightarrow B$. The rule says: if you see a shape $A$ in a design, then you can change it into the shape $B$. The rules of a shape grammar apply recursively, or repetitively, in combination with one another to generate a set of design variations or solutions.

The formal and visual nature of shape grammar rules stands in contrast to Alberti's written and sometimes ambiguous rules. Figure 1 shows a shape rule that corresponds to Alberti's written rule for adding a portico to the front of a temple (see p.13). The shape rule expresses this: If you have a rectangular space or cella as shown on the left side of the rule, then you can add a portico as shown on the right side of the rule. The shapes in the rule have variables or parameters associated with them that specify exactly how the dimensions of the added portico relate to the dimensions of the cella.

How does the shape grammarian use rules? The shape grammarian uses rules very much as Alberti did -for both analysis and design. Analysis grammars are developed to understand and describe designs or design styles ${ }^{1}$ that already exist-from architectural designs to landscape designs to furniture designs to paintings to product designs to mechanical designs. A well-known, early example of an analysis shape grammar is the Palladian villa grammar developed by George Stiny and William Mitchell (1978). The authors based their work on an analysis of Palladio's drawings and written rules for villa plans in The Four Books on Architecture (Palladio, 1997). The shape grammar includes rules for underlying grids, rules for room layouts (figure 2), rules for porticoes, rules for columns, and rules for windows and doors.

The grammar can generate many different Palladian villa plans depending on which rules are applied. Figure 3 shows a small sampling of the design possibilities. Notice that the grammar generates Palladio's own designs as well as new, hypothetical designs in Palladio's style. This is typical of analysis grammars. They generate existing designs as well as new ones in the style of the existing ones.

Shape grammars for design, by contrast with analysis shape grammars, are developed to create solely new and original design possibilities. However, distinctions between analysis and design are slippery. Many design applications of grammars begin with analysis, in particular, the analysis of precedents for a particular design problem. Rules are derived from the precedents and then those rules are used as the starting point for new rules. Which brings us back to Alberti. We saw how Alberti proceeded from analysis to design, and from rules to design practice. How does the shape grammarian do this? 
layouts (redrawn from Stiny and Mitchell, 1978).
2. Sample shape rules for Palladian villa room

1
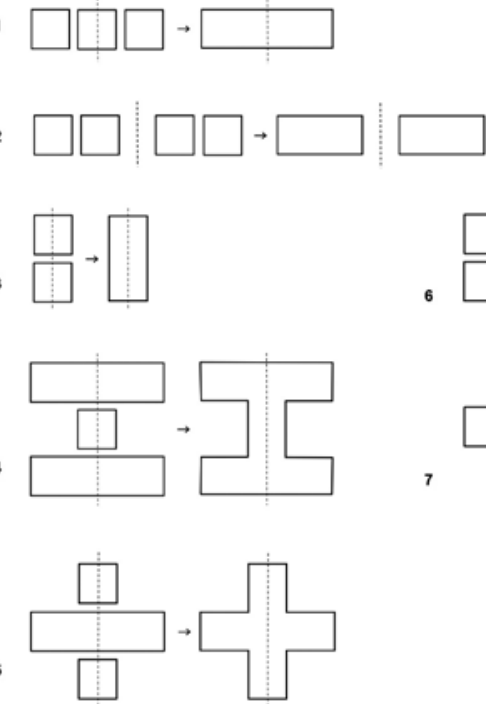
and some new villa designs (right), all generated by the Palladian grammar.
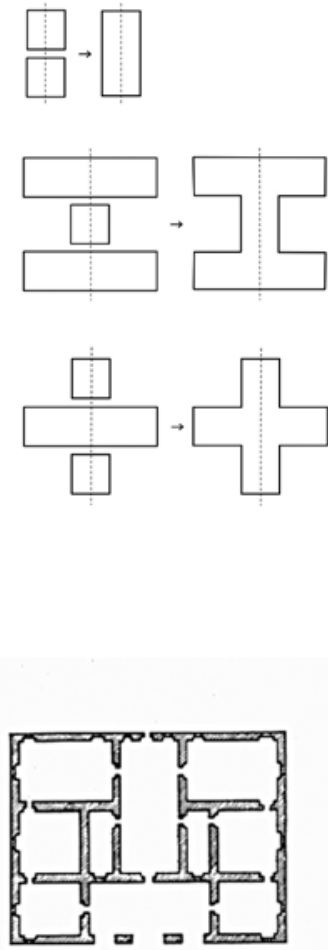

Villa Zeno

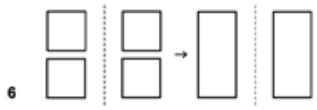
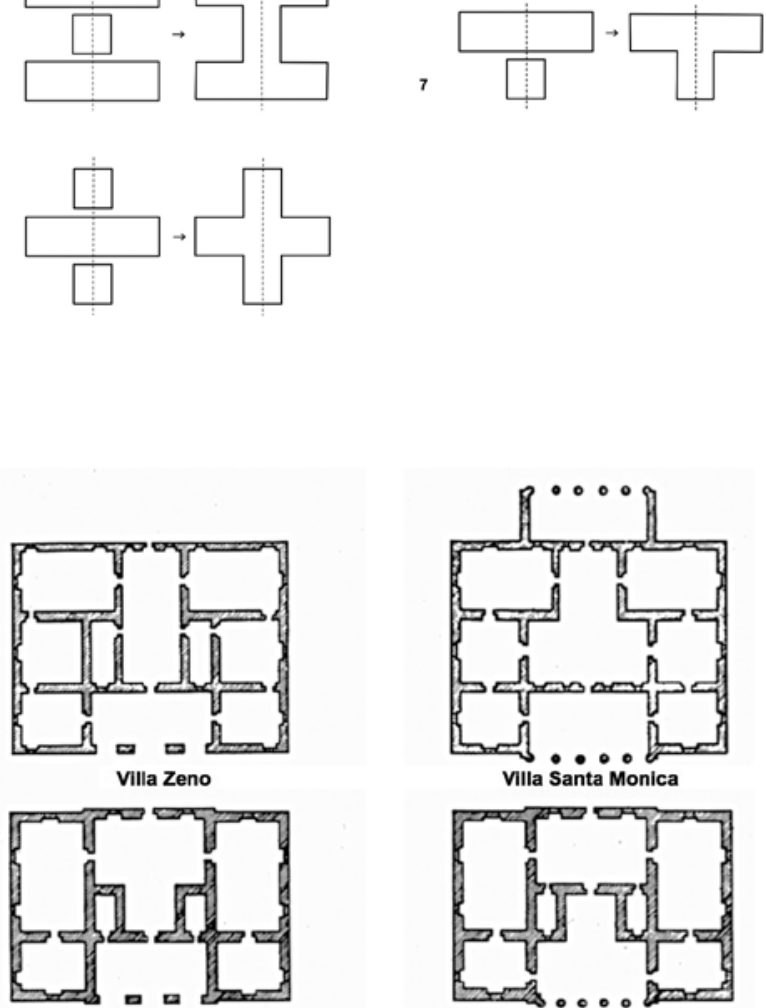

Villa Sarraceno
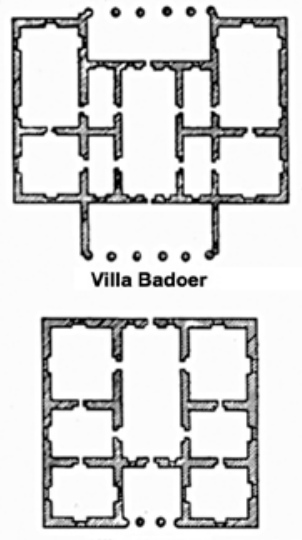

Villa Angarano
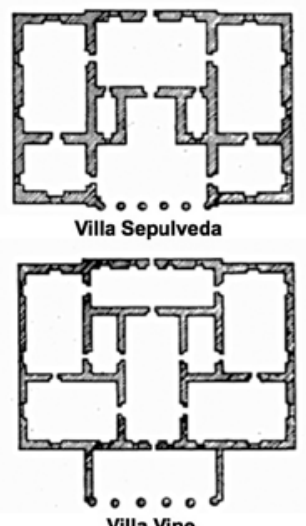

Villa Vine

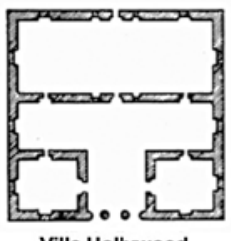

Villa Hollywood 


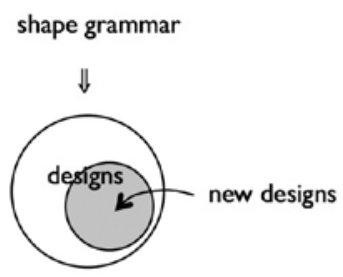

STRATEGY ONE

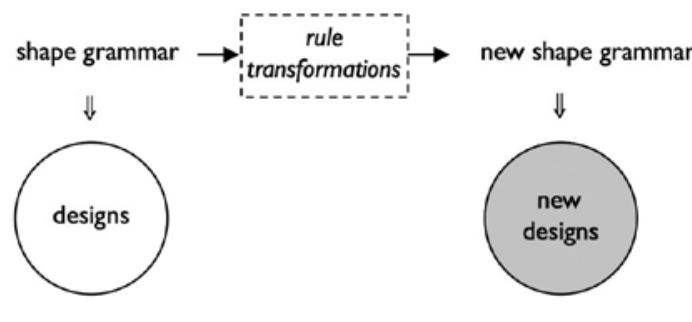

STRATEGY TWO

shape grammar
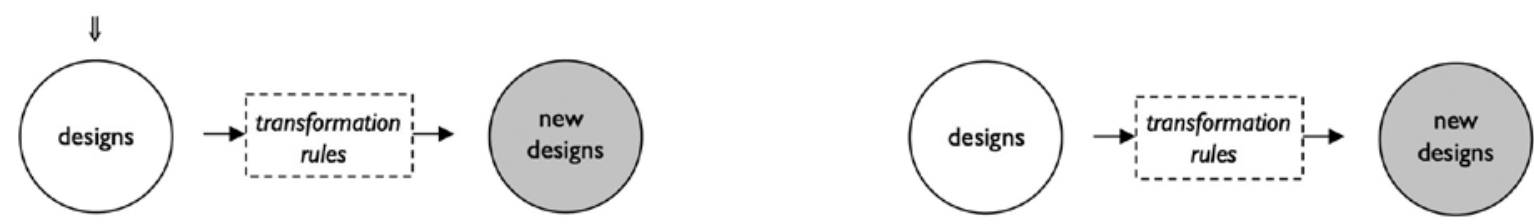

STRATEGY THREE

\section{STRATEGY FOUR}

4. Four computational strategies for bridging from analysis to design. 
Shape grammars: from analysis to design, from rules to practice A survey of work with shape grammars over the past decades reveals four distinct computational strategies for bridging from analysis to original design. The four strategies are illustrated in figure 4 . The starting point for each is the analysis of a set of existing designs, just as the starting point for Alberti was his analysis of classical architecture.

The first strategy is straightforward. The starting point is a set of existing designs, and an analysis shape grammar for these designs. Among the designs generated by the grammar are the original designs and well as new designs - just as with the Palladio grammar. Thus, with just a shape grammar analysis alone, there is the possibility to create new and novel designs. However, the new designs will be constrained to be in the same style as the original ones.

The second strategy begins in the same way as the first, that is, with an analysis shape grammar for the starting set of designs.

And, as before, the designs generated may include new ones. But to extend the design possibilities further and to go beyond the original style, an additional step is taken. Rule transformations are defined. These rule transformations take the rules of the original grammar as input and produce new rules of a new grammar as output. The new grammar generates a new set of designs. The new designs are related to the old ones, but they are in a different style.

The third strategy is similar to the second strategy. It has the same starting point. However, instead of defining transformations that act on the rules of the analysis grammar, transformations are defined that act directly on the generated designs themselves to create new designs. In other words, instead of defining rule transformations, transformation rules are defined. These transformation rules are applied to a design to transform it step-by-step into a new design.

The forth strategy is an abbreviated version of the third strategy. Here, an analysis grammar for the starting set of designs is omitted. As before, transformation rules are defined that are applied to the original designs to generate new designs.

The four strategies were extracted from various case studies with shape grammars over the years. Here, one example of each strategy is presented, though there are numerous other examples. The descriptions of the shape grammars used to illustrate the strategies are brief and impressionistic. The focus here is on the strategies themselves, and not on the shape grammars. Readers are referred to the original studies for further details of the grammars.

\section{Strategy One}

This strategy is exemplified well by the work of José P. Duarte (2005) on Álvaro Siza's Malagueira housing project in Portugal. The goal of Duarte's work was the development of an interactive generative system for designing mass customized housing based Siza's Malagueira designs. Duarte's first step toward this design goal was an in-depth analysis 
of the Malagueira houses. He studied the house designs and worked with Siza directly to make Siza's design rules explicit through a shape grammar. The shape grammar Duarte inferred generated existing Malagueira house designs (see figure 5, top). But, more importantly, the shape grammar was able to generate completely new designs that were customized to client requirements and could potentially be built on the Malagueira site (see figure 5, bottom).

In an experimental follow-up to this project, Duarte invited students in a workshop to break or modify the rules of the shape grammar to accommodate client briefs in ways that diverged from Siza's own practice. This experiment leads to the second strategy.

\section{Strategy Two}

The objective of this strategy is to move beyond a style or system of existing designs to create new, transformed designs. This strategy was explored in detail by Knight (1994) in her computational model for transformations of design. Knight's motives were both analytic and creative: she defined her model as a means both for understanding how design styles evolve over time and for creating new designs on the basis of known ones. Central to her model are rule transformations that apply to the rules of an existing grammar to transform them into new rules of a new grammar for new designs. Rule transformations include three mechanisms: rule change, rule addition, and rule deletion.

Knight conducted several proof-of-concept studies including one on the work of the de Stijl artist Georges Vantongerloo. She traced the evolution of Vantongerloo's paintings over a twenty-year period and identified several distinct stages in his work. Each stage has its own logic, and for each she defined a shape grammar. She then showed how the stages were related by identifying how Vantongerloo experimented with and transformed his rules from one stage to the next. The transformations between consecutive stages were subtle. However, Vantongerloo's final paintings look nothing like his early ones. Interestingly, though, they are easily related through a series of rule transformations. This computational perspective gives new insights into Vantogerloo's thinking and making processes over a long time span. Figure 6 gives a simplified chart illustrating the different stages of Vantongerloo's paintings, the grammar for each stage, a representative painting generated by each grammar, and the rule transformations from one stage to the next.

\section{Strategy Three}

This strategy is similar to the previous one. But here, transformations act at the level of designs, not rules. An example of this strategy comes from a study by Birgul Colakoglu (2001, 2005) on traditional hayat houses in Bosnia. Hayat houses are built around a large shaded gallery - the hayat-open to a garden. Colakoglu's aim was to define a methodology to modify traditional hayat houses to fit a contemporary 
5. A computation of an existing Malagueira house using the Malagueira grammar (redrawn from Duarte, 1990) and several new houses generated by the grammar (from Duarte, 2005).

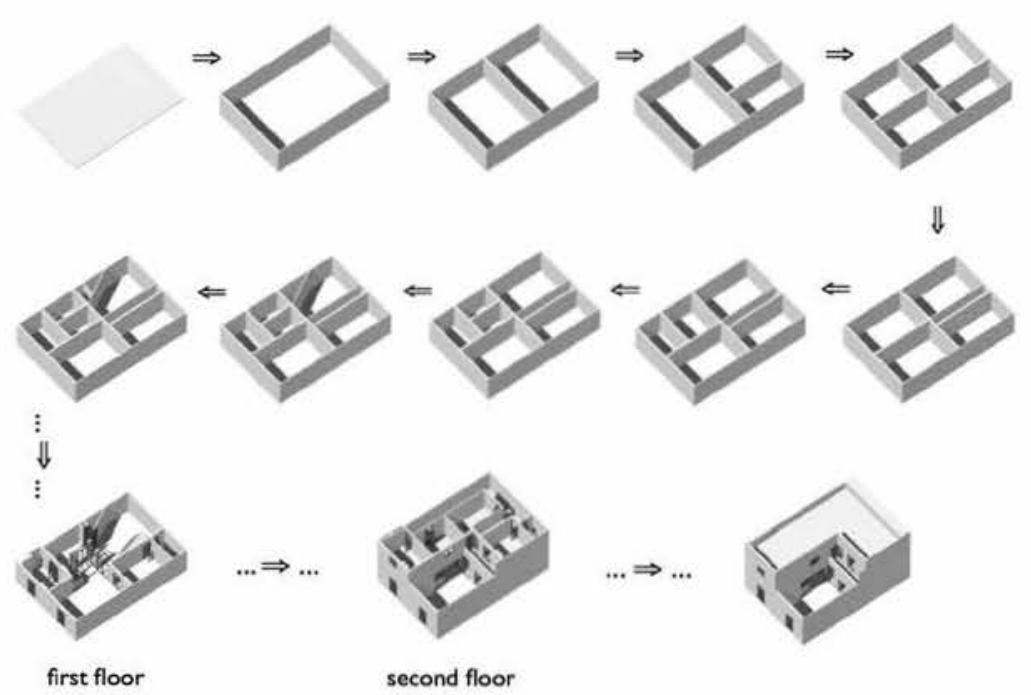

simplified computation of an existing Malagueira house

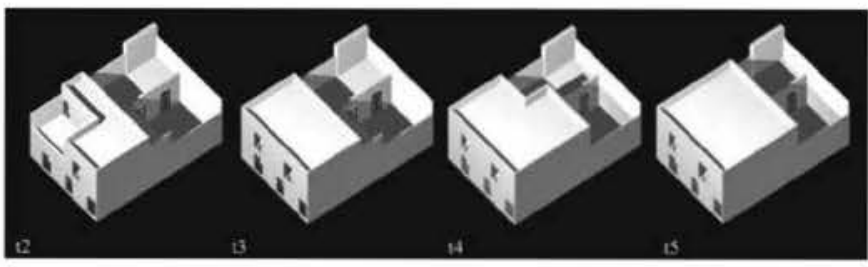

new houses generated by the Malagueira shape grammar 

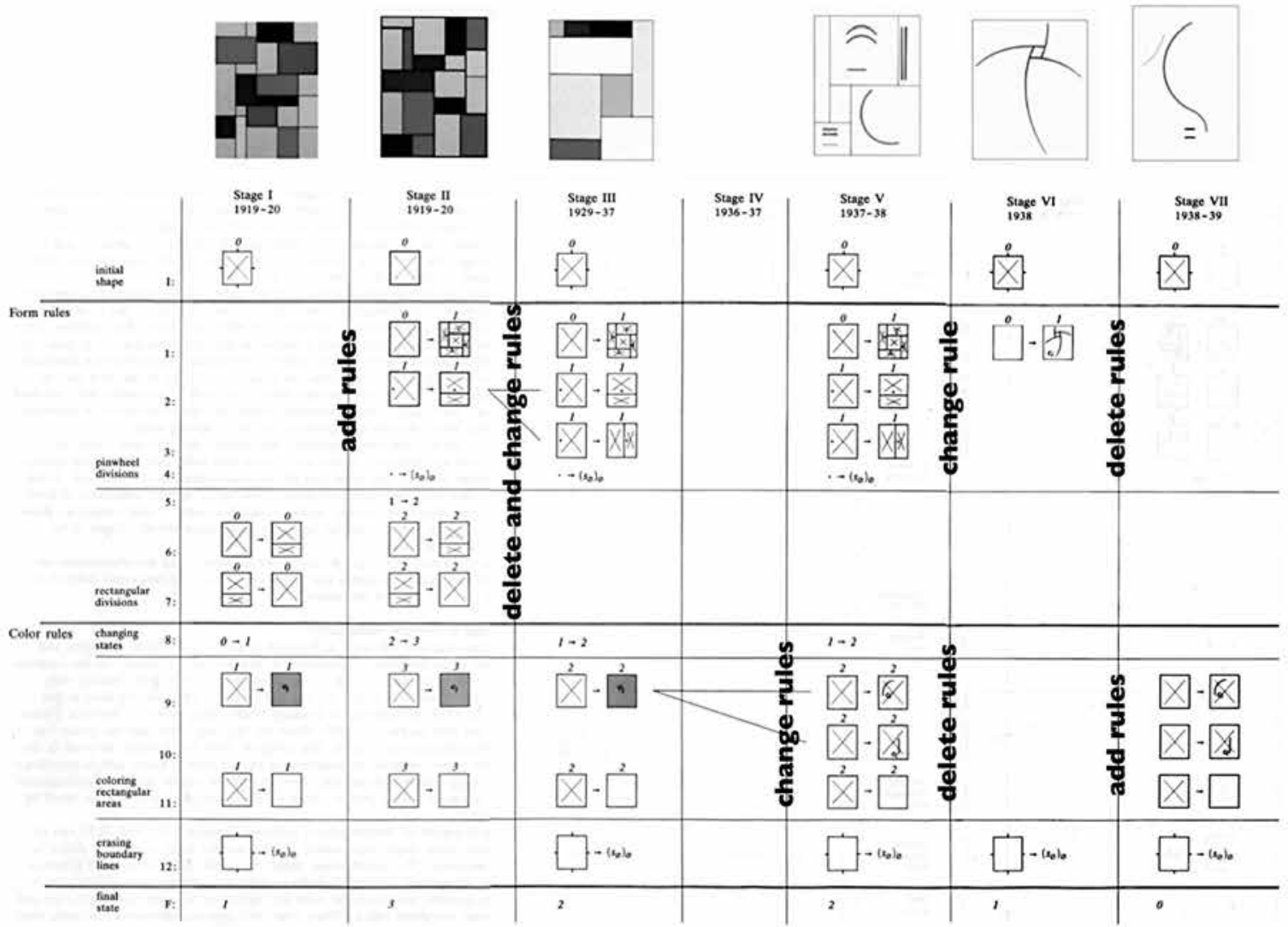

6. Rule transformations in the paintings of Georges Vantongerloo from 1919 to 1939. 
$\longrightarrow$ 居

5
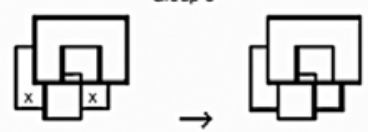

Group 6

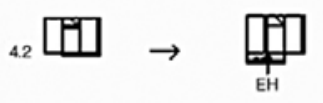

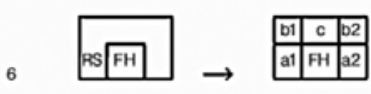

${ }_{43}$ 可 輙

Group 7

$\rightarrow$

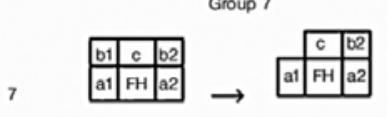

$\rightarrow$ Group 8

EH Extended hayat

FH First-floor hayat

$\begin{array}{ll}\text { RS } & \text { Room space } \\ X & \text { Emergent shape }\end{array}$

sample house variation or transformation rules
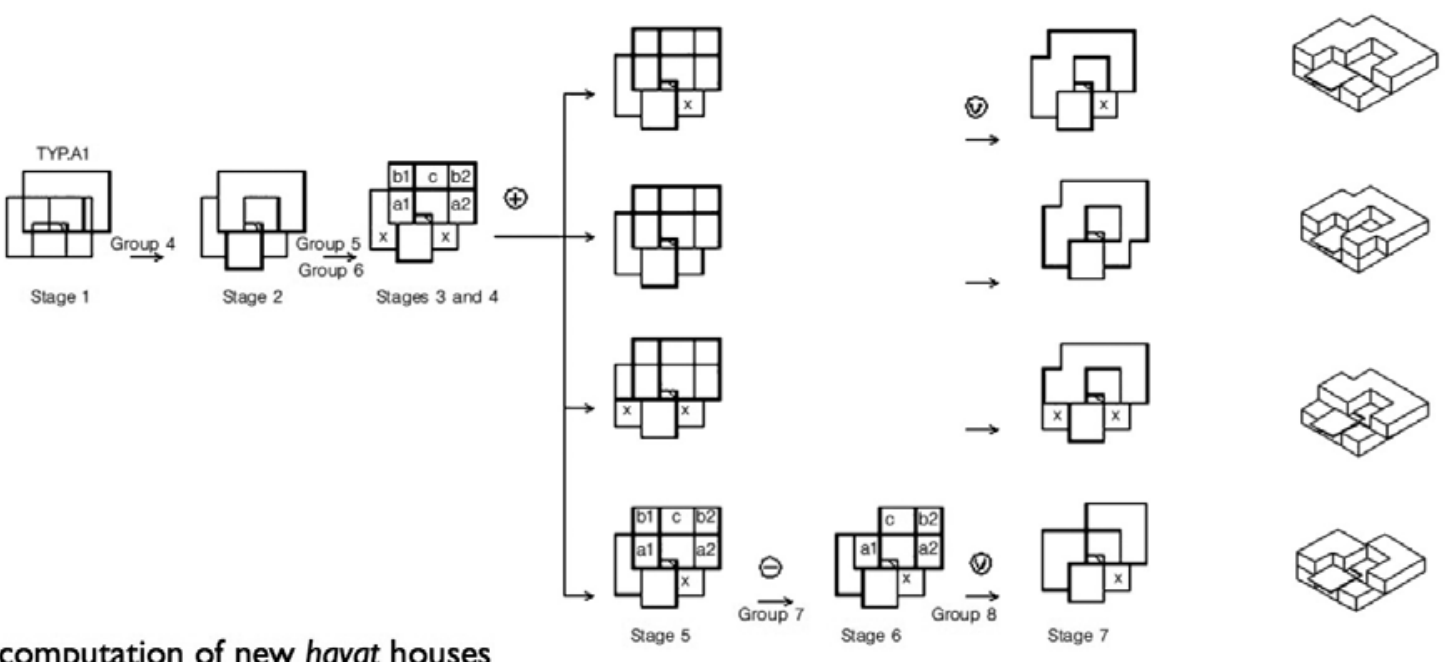

computation of new hayat houses

Stage 5

Stage 6

7. Sample transformation rules for converting traditional hayat houses into houses for contemporary settings (top) and a step-by-step application of transformation rules to generate new houses (bottom) (from Colakaglu, 2005). 
Rule 1.2.d_Enlarge the connection between two rooms (by eliminating part of the walls on both sides of the passageway)

$$
\begin{aligned}
& \mathrm{Fb}_{\text {w }} \quad \mathrm{Fb}_{\text {w }}
\end{aligned}
$$

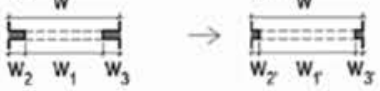

$$
\begin{aligned}
& \mathrm{Ft}
\end{aligned}
$$

Conditions:

Dimensions:

$w 1 \geq 1 / 2 w$

$w \geq 0,9 m$

$w 2, w s \geq 0 m$

Function:

$\mathrm{Fb}, \mathrm{Ft} \in\{$ be.c, be.d, bei, di, li $\} \wedge \mathrm{Fb}=\mathrm{FI}$

\section{Description}

R1. $2 d<D 1: F b, F t ; w, w 1, w_{2}, w_{3}>\rightarrow<D 1: F b, F t, w, w_{1}, w_{2}, w^{\prime}>$

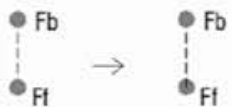

8. A sample rule for transforming an existing Portuguese rabo-de-bacalhau plan into an updated plan (from Eloy and Duarte, 2011).

D brick wall (ub) _L structural wall or column (reinforced concrete or load-bearing masonry) (uc)

IIIII byt partion wal (plaster board) (ul) 
Bosnian context. First, she analyzed hayat houses and derived a shape grammar from her analysis. Next, she applied her grammar to generate traditional houses. Last, she defined transformation rules - rules that apply to traditional designs to transform them, step-by-step, into new designs (see figure 7, top). Basically these rules reconfigure and resize interior spaces while preserving important traditional features, including the hayat. Figure 7 (bottom) shows a step-by-step conversion of a traditional plan into different designs that are compatible with contemporary settings and lifestyles.

\section{Strategy Four}

With this strategy, as with the previous one, transformations occur at the level of designs. But here, the analysis of the starting designs with a shape grammar is omitted. The focus is on the transformation rules. An example of this strategy is from the recent work of Sara Eloy (Eloy, 2011, Eloy and Duarte, 2011) on a building type called rabo-de-bacalhau, or "codfish tail", built in Lisbon, Portugal during the mid-2oth century. Eloy's goal was similar to Colakoglu's. Her intention was to define a methodology to renovate or rehabilitate existing housing stock to fit contemporary needs, including the integration of new information and communication technologies.

Eloy surveyed a broad range of existing rabo-de-bacalhau houses, and analyzed their compositional, functional, structural, social, and other features. She identified four basic building types. She then defined transformation rules to rehabilitate these buildings. Figure 8 gives a sample rule for enlarging a passageway between adjacent rooms by partially demolishing walls.

Figure 9 shows an application of the transformation rules to convert an existing plan, step-by-step, into a reconfigured, contemporary plan. The rules used in this computation were chosen to generate a layout for a specific functional program and family type. Other transformation rules could be applied to the same existing plan to generate alternative new plans that fit other functional programs. A very rich set of contemporary design variations can be generated with the transformation rules.

\section{Next Steps}

The four computational strategies identified here are all productive ways to progress from an analysis of design precedents and traditions to new designs for new contexts and intentions. All but one strategy use rules in the analysis stage, just as Alberti did. Once an analysis is done, however, all four strategies leverage the power of generative rules to create a multitude of new design solutions on the basis of the existing ones. Depending on the design problem at hand, one or more of the strategies - or even some combination of them-might be more or less appropriate to use. 
II 3 bedrooms needed, choose front wing for private area

Choose strategy: 2

Original dwelling

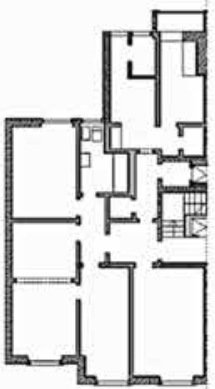

Step 0 : assignment of kitchen

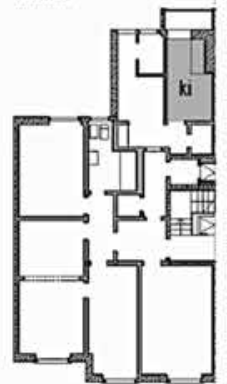

Step 1: assignment of bedrooms

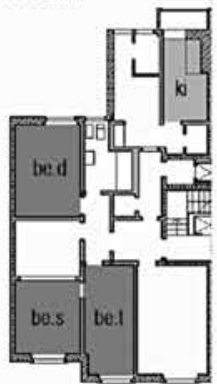

fule 1.1
Step 1: assignment of private bathrooms

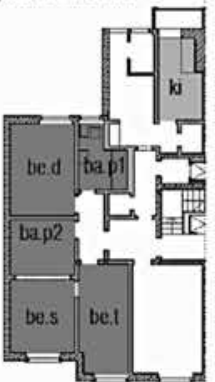

fule 1.3
Step 1: adapting bedroom shape

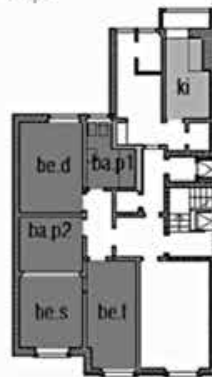

Nule 120 . Blininating doe spening (Detween ba p2 and bes) rule 120 Elininating doox opening (otween bes sad be.t)
Step 1: adapting bedroom shape

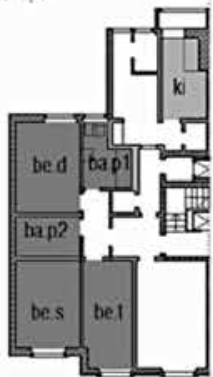

Pile $12 \mathrm{~h}$ Epandingaroon (dermolishing eisting wall and adting a new one)
Step 1: adapting bedroom shape

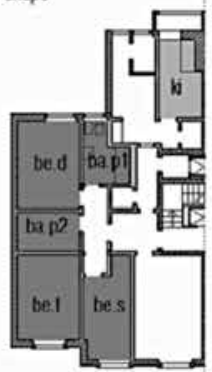

nite 14 Change assignmest of bedroons due to area crieria nule 1. . Remone bectoomarea

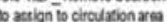

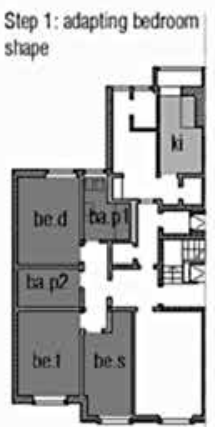

rule $1.2 e$ Connecting two adjacent areas
Step 2: assignment of

living and dining room

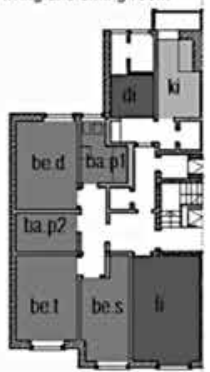

nle 21
Step 2: adapting living and dining room shape

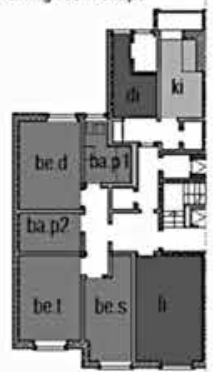

rule 2.2a_adding adjacent ares
Step 2: adapting living and dining room shape

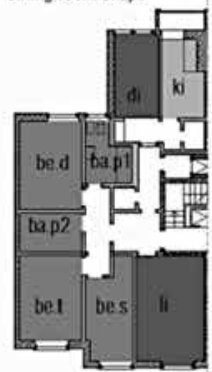

rule $22 a$ _ading adjacent area
.... final layout

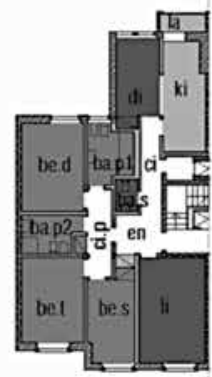

9. A step-by-step conversion of an existing Portuguese rabo-de-bacalhau plan into a reconfigured, contemporary plan (redrawn from Eloy and Duarte, 2011).

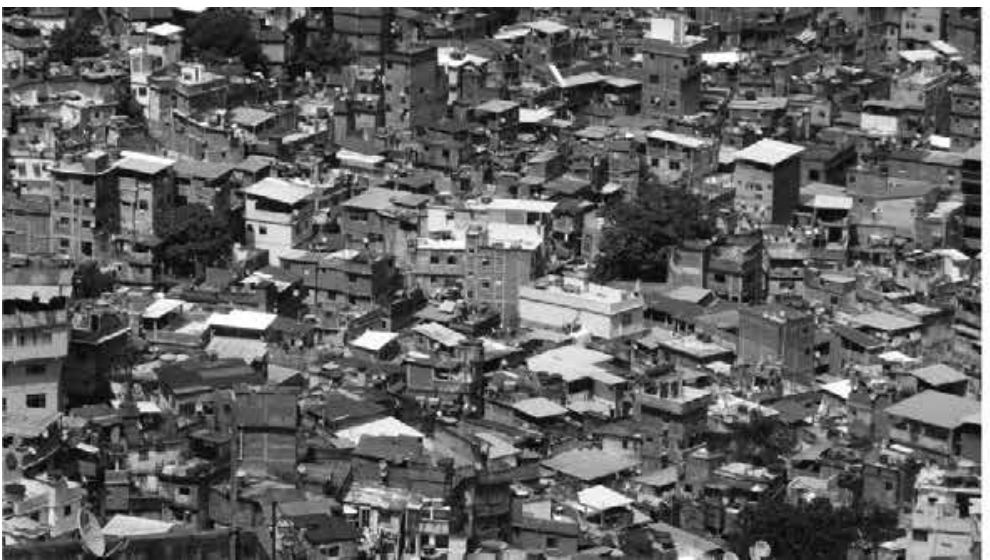

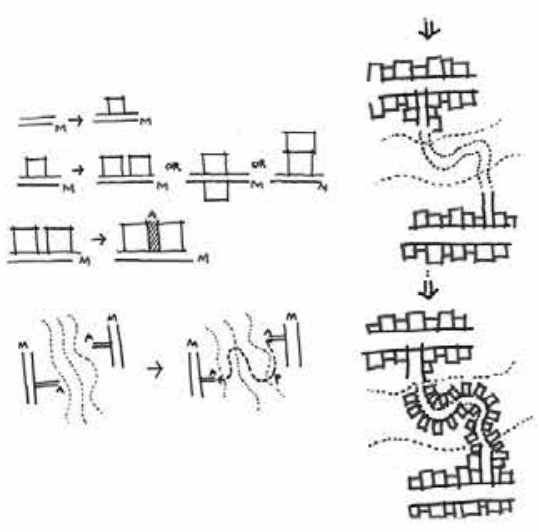

10. The favela Rocinha (left). Preliminary circulation rules for a favela and a partial computation of a favela plan (right, drawing courtesy of Rizal Muslimin). 
A current work-in-progress, for example, is open to one or more of these strategies. This new work is a study of the favela in Brazil, led by this author together with colleagues Maria Angela Dias of the Federal University of Rio de Janeiro, Brazil and Gabriela Celani of the State University of Campinas, Brazil2 ${ }^{2}$. Favelas are communities of migrants who have taken over land illegally and built their own houses and businesses from materials that are inexpensive and readily accessible. Basic services are minimal, and residents live in cramped, impoverished, and unhealthy conditions. Nonetheless, most residents are rightly proud of the homes and communities they build. The short-term goal of the favela study is to determine the rules - the shape grammar-underlying the growth of built form in the largest and most densely populated favela in Brazil-the favela Rocinha located in Rio de Janeiro. The long-term goal is to use the grammar analysis as the foundation for innovative and practical design interventions in Rocinha or other favelas, or perhaps to assist in the design of new social housing projects.

Growth in Rocinha is very much an unplanned, bottom-up, and opportunistic process, leading to irregular, random, and organic-looking settlements. Yet despite the unorganized, chaotic appearance of the favela, we (researchers of this study) uncovered a number of fundamental rules underlying circulation and building patterns, as well as details of building masses. A photo of Rocinha together with some early sketches of rules for houses and allies, and a partial computation with the rules are shown in figure 10. An important and unique principle of favela development is that circulation follows from built space not vice versa. The rules begin to reflect this.

The next step in our study is to develop the Rocinha grammar in more detail and with a more nuanced understanding of the reasons behind the rules. We then plan to work out how and whether to transform the grammar for new building interventions and practices. To do so, we need to understand which rules are important to preserve and which are not. For example, favelas have many positive and progressive features with socio-cultural, aesthetic, functional, and other benefits. The adaptation of buildings to natural features of the terrain leads to a natural diversity in building heights and plans. The growth of circulation paths as needed builds local-scale community connections within a very large and complex settlement.

To conclude, we are attempting to be modern day Alberti's. We are decoding a very different kind of architecture and for a very different "client". But the ambition to understand architecture with rules and to transform and adapt rules in meaningful ways for changing or new conditions and design intentions is very much in the spirit of Alberti. 
$1 \rightarrow$ The term "style" is used in this paper in a general sense to denote a set

of designs that are grouped together with respect to any criteria: composition, materials, construction process, time period, region, or other.

$2 \rightarrow$ The favela project was launched through a collaborative workshop held

at the Federal University of Rio de Janeiro, Brazil in March of 2013. Along

with Professors Celani, Dias, and Knight, doctoral students Rizal Muslimin of

MIT and Danusa Gani of the Federal University of Rio de Janeiro played major

roles in the workshop.

\section{Bibliography}

Alberti, L. B. (1988). On the Art of Building in Ten Books. (J. Rykwert, N. Leach, \& R. Tavernor, Trans.). Cambridge, Mass.: MIT Press.

Colakoglu, B. (2001). Design by Grammar: An Algorithmic Design in an Architectural Context. PhD dissertation, Department of Architecture, Massachusetts Institute of Technology, Cambridge, MA.

Colakoglu, B. (2005). Design by grammar: an interpretation and generation of vernacular hayat houses in contemporary context. Environment and Planning B: Planning and Design, 32, 141-149.

Duarte, J. P. (1999). Malagueria, Álvaro Siza Vieira 1977/99. Retrieved from http://gaudi.fa.utl. pt/ jduarte/malag/.
Duarte, J. P. (2005). Towards the mass customization of housing: the grammar of Siza's houses at Malagueira. Environment and Planning B: Planning and Design, 32, 347-380.

Eloy, S. (2011). A transformation grammar-based methodology for housing rehabilitation: meeting contemporary functional and ICT requirements, $\mathrm{PhD}$ thesis, IST TU Lisbon.

Eloy, S., \& Duarte, J. P. (2011) A Transformation Grammar for Housing Rehabilitation. Nexus Network Journal, 13 (1), 49-71.

Gombrich, E. H. (1995). The Story of Art (16th ed.). London: Phaidon Press.

Knight, T. W. (1992). Designing with Grammars. In G. Schmitt (Ed.) Computer-Aided Architectural Design (pp. 33-48). Wiesbaden: Verlag Viewag.
Knight, T. (1999). Shape Grammars in Education and Practice: History and Prospects. International Journal of Design Computing 2, http://www.mit. edu/ tknight/IJDC/.

Knight, T. W. (1994). Transformations in Design. Cambridge, UK: Cambridge University Press.

-

Palladio, A. (1997). The Four Books on Architecture (R. Tavernor \& R. Schofield. Trans.). Cambridge, Mass.: MIT Press.

Stiny, G., \& Mitchell, W. J. (1978). The Palladian grammar. Environment and Planning B 5(1), 5-18.

Tavernor, R. (1998). On Alberti and the Art of Building. New Haven: Yale University Press. 